\title{
Effects of Some Edible Coating on the Quality and Shelf-Life of Pioneer Plum Fruits (Prunus salicina $\mathrm{L}_{\text {.) }}$ at Room Temperature
}

\author{
M. F. Maklad \\ Department of Horticulture, Faculty of Agriculture, Ain shams \\ University, Cairo, Egypt.
}

\begin{abstract}
7 HE INVESTIGATION was carried out during 2013 and 2014 1 seasons from selected 4 years old plum cv. Pioneer grafted on Okinawa rootstock located in a commercial orchard at El-Kattatba region, Egypt. Edible coating materials have been used for preserving the quality and safety of fresh fruits. The objective of this research was to evaluate the effect of jojoba oil, paraffin oil, glycerol and Arabic gum as edible coatings on the shelf-life period and quality of Pioneer plum fruits at room temperature $\left(25 \pm 2^{\circ} \mathrm{C}\right)$. The results indicated that coated plums showed a significant delay in the change of weight loss \%, firmness, total soluble solids, and decay percentage compared to uncoated ones. The results suggested using jojoba oil, glycerol and Arabic gum as edible coatings instead of paraffin oil.
\end{abstract}

Keywords: Coatings, Jojoba oil, Paraffin oil, Glycerol, Arabic gum, Pioneer plum, Quality and Shelf life.

The plum is classified as a climacteric fruit, showing a peak in ethylene production and respiration during development. However, two distinct types of ripening behavior have been observed for several cultivars (Abdi et al., 1997 and Zuzunaga et al., 2001). Those showing a typical climacteric behavior and those considered suppressed climacteric (Abdi et al., 1998). Plums have a short postharvest life compared with the other climacteric temperate fruits such as apples and pears (Kader, 2000). The extension of fruit shelf life is an important goal to be attained. Different preservation methodologies have been studied. One method of extending post-harvest shelf life is the use of the edible coatings (Baldwin et al., 1995). Edible coatings provide a semipermeable barrier against oxygen, carbon dioxide (CO2) moisture and solute movement, thereby reducing respiration, water loss and oxidation reaction rates (Baldwin et al., 1999 and Park, 1999). Proteins, lipids and polysaccharides are the main constituents of edible films and coatings. Polysaccharide-based coatings i.e. Alginate, pectin's, cellulose and derivatives, starch and sucrose poly esters have been used to extend the shelf-life of fruits and vegetables (Nisperos-Carriedo, 1994, Nussinovitch, 1997 \& 2000, Mancini \& McHugh, 2000, Yang \& Paulson, 2000, Rhim, 2004, and Rojas-Grau et al., 2007). In this respect, mineral hydrocarbon MHC-based coatings are used on specific types of fruits and vegetables to prevent the loss of moisture, protect the commodities from bruising and add various degrees of sheen. MHC-based coatings may consist of one compound, such as mineral oil, or may consist of a mixture of MHC compounds, such as mineral oil, paraffin oil 
and petrolatum, blended to modify the melting point of the coating. Furthermore, a coating may be $100 \%$ MHC or the MHC product (s) may be part of a waterbased emulsion, especially if a mold inhibitor or insecticide is added. When mineral oil is used, it is typically a low viscosity oil $<15$ cmpoise at $40^{\circ} \mathrm{C}$ (Heimbach et al., 2002 and El-Anany et al., 2009).

The objectives of this research were to evaluate the potential of jojoba oil, glycerol and Arabic gum on the shelf-life and quality of Pioneer Plum and to compare the effect of these alternative materials to that of paraffin oil.

\section{Plum samples}

\section{Materials and Methods}

Commercially ripening plums (Prunus salicina L.) were hand - harvested at the maturity stage (TSS 13.63, firmness 4.68 inch / Lb2, average weight $59.44 \mathrm{~g}$ and red yellowish of skin color in early June during 2013 and 2014 seasons from selected 4 years old cv Pioneer grafted on Okinawa rootstock located in a commercial orchard at El-Kattatba region, Egypt. Fruits were selected for uniformity, shape, color and size and any blemished or diseased fruits were discarded, and immediately transported to the laboratory of fruit breeding Dept. of Horticulture, Faculty of Agriculture, Ain Shams Univ., Egypt.

Edible coatings

Paraffin oil and Glycerol (99.0\%) were of reagent grade (Gomhoria Co., Amireya-Cairo, Egypt). Jojoba (Simmondsia chinensis) oil (Alkanz Co., Zagazig, Egypt) and Arabic gum (Giza, Egypt) were of commercial grade. Arabic gum solution $(15 \% \mathrm{w} / \mathrm{v})$ was prepared by dissolving Arabic gum in distilled water and heated at $40^{\circ} \mathrm{C}$, while stirring until the solution became clear.

\section{Coating treatments}

Plum fruits were washed with distilled water to remove any dirt. The fruits were divided randomly into 5 groups (100 plums/treatment):

- Control group (untreated)

- Fruits were coated with thin layer of Jojoba oil

- Fruits were coated with thin layer of paraffin oil

- Fruits were coated with thin layer of Glycerol

- Fruits were coated with thin layer of Arabic gum

The treated and untreated fruits were put at room temperature $\left(25 \pm 2{ }^{\circ} \mathrm{C}\right)$. The physicochemical tests were conducted at the beginning of the experiment duration (zero time) and after 7, 15, 21 and 30 days of coating treatments.

Data on the following parameters was recorded:

- Weight Loss \%: Plums were weighed at the beginning of the experiment just after treatments application and every seven days interval. Weight loss was expressed as the percentage loss of the initial total weight.

- Fruit Firmness (Kgf): Fruit firmness was measured on the equatorial zone of the both cheeks after removing fruit skin using Tester (GY-1, China) equipped 
with a 2-mm plunger tip a digital basic force gauge. Values were expressed in kilo gram force $(\mathrm{Kgf})$.

- T.S.S: From 5 plum fruits juice was extracted with an electrical juicer and used for the determination of Soluble Solids content (SSC) measured as Brix \% with a digital refractometer (A.O.A.C. 1990).

- Decay Fruits \%: The number of decayed fruits was periodically recorded and expressed as a percentage from the total fruit number.

Statistical analysis: data of the two seasons were arranged and statistically analyzed using Mstatic (M.S.) software (freed 1988). The comparison among means of the different treatments was determined, as illustrated by Snedecor and Cochran (1982). Means were compared using the LSD values of $5 \%$ level.

\section{Results and Discussion}

Weight loss percentage:

Figure 1 shows the changes of weight loss percentages of coated and uncoated plum (control) during the different shelf life periods. Generally, the weight loss $\%$ increased gradually during shelf life periods at $\left(25 \pm 2^{\circ} \mathrm{C}\right)$ with all coating treatments. The primary mechanism of moisture loss from fresh fruits and vegetables is by vapor-phase diffusion driven by a gradient of water vapor pressure at different locations (Yaman and Bayoindirli, 2002). On the other hand, respiration causes a weight reduction because a carbon atom is lost from the fruit in each cycle (Labuza, 1984). However, coating process caused a significant decrease in weight loss compared with control sample. Control samples had significantly higher weight loss value $(5.88 \%$ and $6.06 \%)$, while plum samples coated with Jojoba oil had significantly the lowest weight loss values $(4.35 \%$ and $4.66 \%)$ in the both seasons, respectively. The results especially in the control treatment supported by Nasr et al. (2013) who found in pioneer plum cultivar, the weight loss $\%$ was increased after different 7,14,21 and 28 days intervals at $\left(20 \pm 2^{\circ} \mathrm{C}\right)$, where it was $3.23,4.33,6,11,7.89$ and 3.17, $5.86,6.54,8.10$, in the two seasons of those results, respectively. On the other hand, This reduction in weight loss was probably due to the effects of these coatings as a semi permeable barrier against oxygen, carbon dioxide, moisture and solute movement, thereby reducing respiration, water loss and oxidation reaction rates (Baldwin et al., 1999 and Park, 1999).

\section{Firmness}

Flesh firmness is one of the most important parameters as regards consumer acceptance and eating quality of plums. As shown in Table 1 firmness significantly decreased at interval shelf life period in both treated and untreated fruits. Control samples clearly had the lowest firmness (2.93 amd $2.98 \mathrm{~kg} \mathrm{~cm}-2$ ) while plums coated with jojoba oil, glycerol and Arabic gum retained the highest firmness (4.48, 3.83, $3.98 \mathrm{~kg} \mathrm{~cm}-2$ and 4.37, 3.45, $3.84 \mathrm{~kg} \mathrm{~cm}-2)$ 


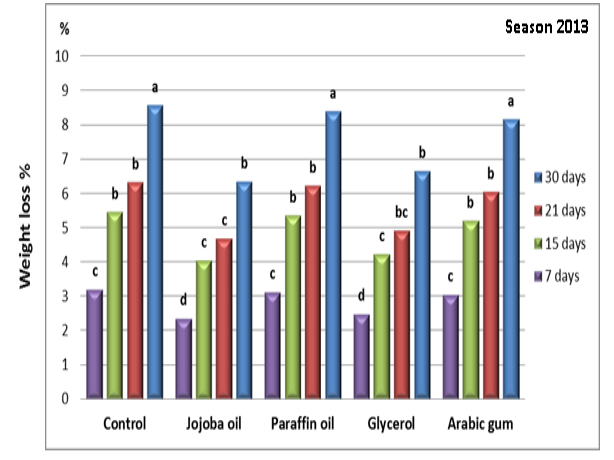

Coating treatments

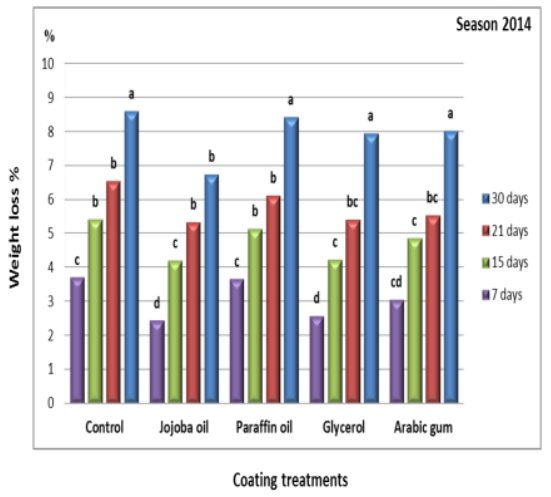

Fig. 1. Effect of coating with jojoba oil, paraffin oil, glycerol and arabic gum on weight loss percentages of Pioneer plum fruits after different shelf life periods at room temperature $\left(25 \pm 2^{\circ} \mathrm{C}\right)$ during 2013 and 2014 seasons.

TABLE 1. Effect of coating with jojoba oil, paraffin oil, glycerol and arabic gum on firmness of Pioneer plum fruits after different shelf life periods at room temperature $\left(25 \pm 2^{\circ} \mathrm{C}\right)$ during 2013 and 2014 seasons.

\begin{tabular}{|c|c|c|c|c|c|c|}
\hline Treatments & \multirow[b]{2}{*}{ Control } & \multirow[b]{2}{*}{$\begin{array}{c}\text { Jojoba } \\
\text { oil }\end{array}$} & \multirow[b]{2}{*}{$\begin{array}{l}\text { Paraffin } \\
\text { oil }\end{array}$} & \multirow[b]{2}{*}{ Glycerol } & \multirow[b]{2}{*}{$\begin{array}{l}\text { Arabic } \\
\text { gum }\end{array}$} & \multirow[b]{2}{*}{ Mean } \\
\hline $\begin{array}{l}\text { Shelflife period } \\
\text { (days) }\end{array}$ & & & & & & \\
\hline \multicolumn{7}{|c|}{ Season 2013} \\
\hline 7 days & $4.60 \mathrm{a}$ & $4.59 \mathrm{a}$ & $3.73 \mathrm{~b}$ & $3.95 \mathrm{ab}$ & $4.13 \mathrm{ab}$ & $4.20 \mathrm{~A}$ \\
\hline 15 days & $3.44 \mathrm{c}$ & $4.50 \mathrm{a}$ & $3.60 \mathrm{bc}$ & $3.85 \mathrm{ab}$ & $4.00 \mathrm{ab}$ & $3.88 \mathrm{AB}$ \\
\hline 21 days & $2.41 \mathrm{~d}$ & $4.47 \mathrm{a}$ & $3.54 \mathrm{c}$ & $3.81 \mathrm{bc}$ & $3.95 \mathrm{ab}$ & $3.63 \mathrm{AB}$ \\
\hline 30 days & $1.27 \mathrm{~d}$ & $4.39 \mathrm{ab}$ & $3.41 \mathrm{c}$ & $3.71 \mathrm{bc}$ & $3.84 \mathrm{ab}$ & $3.32 \mathrm{~B}$ \\
\hline Mean & $2.93 \mathrm{C}$ & $4.48 \mathrm{~A}$ & $3.57 \mathrm{~B}$ & $3.83 \mathrm{AB}$ & $3.98 \mathrm{AB}$ & \\
\hline \multicolumn{7}{|c|}{ Season 2014} \\
\hline 7 days & $4.39 \mathrm{a}$ & $4.59 \mathrm{a}$ & $3.59 \mathrm{ab}$ & $4.00 \mathrm{ab}$ & $4.72 \mathrm{a}$ & $4.26 \mathrm{~A}$ \\
\hline 15 days & $3.47 \mathrm{bc}$ & $4.48 \mathrm{a}$ & $3.58 \mathrm{ab}$ & $3.59 \mathrm{ab}$ & $4.14 \mathrm{a}$ & $3.85 \mathrm{~A}$ \\
\hline 21 days & $2.50 \mathrm{de}$ & $4.31 \mathrm{ab}$ & $3.18 \mathrm{c}$ & $3.13 \mathrm{c}$ & $3.44 \mathrm{bc}$ & $3.31 \mathrm{AB}$ \\
\hline 30 days & $1.59 \mathrm{e}$ & $4.10 \mathrm{ab}$ & $3.17 \mathrm{c}$ & $3.10 \mathrm{~cd}$ & $3.06 \mathrm{~d}$ & $3.00 \mathrm{~B}$ \\
\hline Mean & $2.98 \mathrm{C}$ & $4.37 \mathrm{~A}$ & $3.38 \mathrm{~B}$ & $3.45 \mathrm{AB}$ & $3.84 \mathrm{~A}$ & \\
\hline
\end{tabular}

Fruits coated with paraffin oil were significantly less firm than the other treated samples 3.57 and $3.38 \mathrm{~kg} \mathrm{~cm}-2$ in the both seasons, respectively. Nevertheless, this edible coating still largely reduces firmness losses if compared to untreated fruits. The retention of firmness can be explained by retarded degradation of insoluble protopectins to the more soluble pectic acid and pectin. During fruit ripening, polymerization or shortening of chain length of pectin substances occurs with an increase in pectin esterase and polygalactronase activities (Yaman and Bayoindirli, 2002).

Egypt. J. Hort. Vol. 42, No. 1 (2015) 


\section{Soluble Solids content}

The results presented in Table 2 show the changes of SSC. Values of coated and uncoated plum (control) during shelf life periods. Data showed that Jojoba oil coating treatments had significantly the highest level of SSC value was $14.19 \%$ and $14.24 \%$ in both seasons, respectively observed when use jojoba oil as a coating material in the both seasons of study. The means SSC values of plum coated with paraffin oil, glycerol, and Arabic gum compare with a control treated were ranged between 13.28 to 13.81 Brix in the first season and between 13.15 to 13.48 Brix of SSC values. Similar effects were reported by Kittur et al., (2001) for banana and mango coated with polysaccharide-based coatings.

TABLE 2. Effect of coating with jojoba oil, paraffin oil, glycerol and arabic gum on Soluble Solids content (SSC) of Pioneer plum fruits after different shelf life periods at room temperature $\left(25 \pm 2^{\circ} \mathrm{C}\right)$ during 2013 and 2014 seasons.

\begin{tabular}{|c|c|c|c|c|c|c|}
\hline $\begin{array}{l}\text { Treatments } \\
\begin{array}{l}\text { Shelf life period } \\
\text { (days) }\end{array}\end{array}$ & Control & $\begin{array}{c}\text { Jojoba } \\
\text { oil }\end{array}$ & $\begin{array}{c}\text { Paraffin } \\
\text { oil }\end{array}$ & Glycerol & $\begin{array}{c}\text { Arabic } \\
\text { gum }\end{array}$ & Mean \\
\hline \multicolumn{7}{|c|}{ Season 2013} \\
\hline 7 days & $13.74 \mathrm{ab}$ & $13.91 \mathrm{ab}$ & $13.68 \mathrm{~b}$ & $13.03 \mathrm{c}$ & $13.60 \mathrm{~b}$ & $13.59 \mathrm{~A}$ \\
\hline 15 days & $13.98 \mathrm{ab}$ & $14.77 \mathrm{ab}$ & $14.01 \mathrm{a}$ & $13.78 \mathrm{ab}$ & $14.20 \mathrm{a}$ & $14.14 \mathrm{~A}$ \\
\hline 21 days & $13.29 \mathrm{ab}$ & $14.13 \mathrm{a}$ & $13.88 \mathrm{ab}$ & $13.34 \mathrm{~b}$ & $13.90 \mathrm{ab}$ & $13.70 \mathrm{~A}$ \\
\hline 30 days & $12.60 \mathrm{c}$ & $13.97 \mathrm{ab}$ & $13.52 \mathrm{~b}$ & $12.99 \mathrm{~b}$ & $13.56 \mathrm{~b}$ & $13.32 \mathrm{~B}$ \\
\hline Mean & $13.40 \mathrm{~B}$ & $14.19 \mathrm{~A}$ & $13.77 \mathrm{AB}$ & $13.28 \mathrm{~B}$ & $13.81 \mathrm{AB}$ & \\
\hline \multicolumn{7}{|c|}{ Season 2014} \\
\hline 7 days & $14.04 \mathrm{a}$ & $14.00 \mathrm{a}$ & $13.24 \mathrm{bc}$ & $12.95 \mathrm{c}$ & $13.00 \mathrm{bc}$ & $13.44 \mathrm{AB}$ \\
\hline 15 days & $13.98 \mathrm{a}$ & $14.78 \mathrm{a}$ & $13.93 \mathrm{a}$ & $13.54 \mathrm{~b}$ & $13.80 \mathrm{ab}$ & $14.00 \mathrm{~A}$ \\
\hline 21 days & $13.29 \mathrm{~b}$ & $14.22 \mathrm{a}$ & $13.59 \mathrm{~b}$ & $13.22 \mathrm{bc}$ & $13.12 \mathrm{c}$ & $13.48 \mathrm{AB}$ \\
\hline 30 days & $12.60 \mathrm{~d}$ & $13.99 \mathrm{a}$ & $13.17 \mathrm{bc}$ & $12.89 \mathrm{c}$ & $12.81 \mathrm{~cd}$ & $13.09 \mathrm{~B}$ \\
\hline Mean & $13.47 \mathrm{~B}$ & $14.24 \mathrm{~A}$ & $13.48 \mathrm{~B}$ & $13.15 \mathrm{C}$ & $13.18 \mathrm{C}$ & \\
\hline
\end{tabular}

Decay percentage:

Data summarized in Fig. 2 shows the changes of decay percentage values of coated and uncoated plum (control) during shelf life periods. No decay signs were observed till the first week after the beginning of shelf life period. Coating significantly reduced decay compared to control sample without coating treatment during shelf life periods. Decay percentage of control sample was ranged between $17.25 \%$ and $16.89 \%$ which was higher than decay percentage of plum coated with paraffin oil, glycerol and Arabic gum, respectively. Jojoba oil was recorded the lowest value of decay percentage $(8.46 \%$ and $9.23 \%)$ compared with the other coating materials in the both seasons of the study.

This decrease in decay percentages of treated samples was probably due to the effects of these coatings on delaying senescence, which makes the commodity more vulnerable to pathogenic infection as a result of loss of cellular or tissue integrity (Patricia et al., 2005). These results are in a good agreement with the findings by Bai et al. (2003) for Gala apple, coated with $10 \%$ zein. 

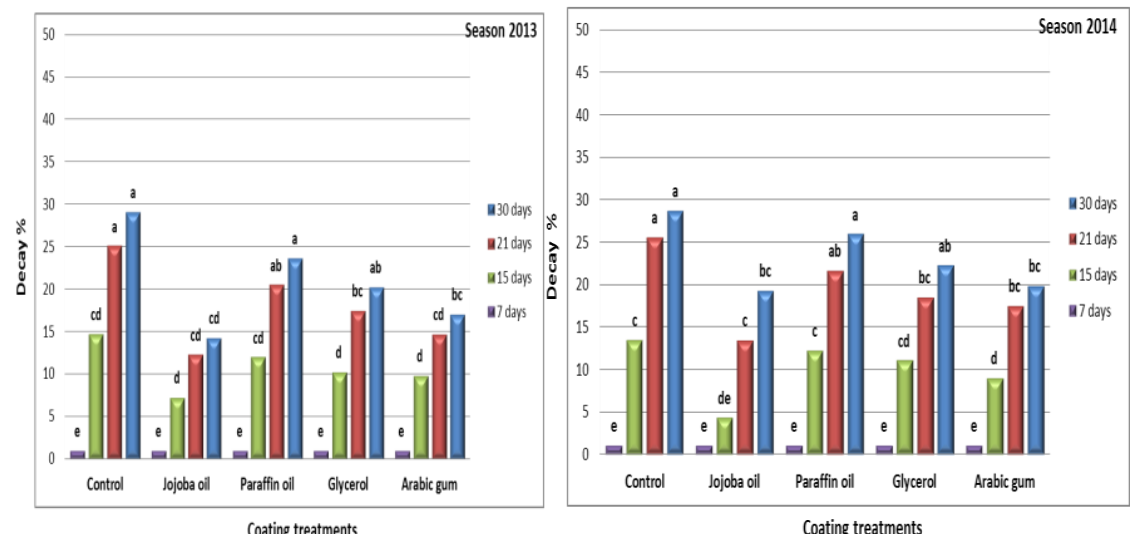

Fig. 2. Effect of coating with jojoba oil, paraffin oil, glycerol and arabic gum on decay percentage of Pioneer plum fruits after different shelf life periods at room temperature $\left(25 \pm 2^{\circ} \mathrm{C}\right)$ during 2013 and 2014 seasons.

They found that coating with zein maintained apple quality similar to a commercial shellac formulation and extended apple shelf life compared with uncoated control. Also, Patricia et al. (2005) indicated that wheat gluten coatings and films extended the shelf life of strawberries and retarded the senescence process.

\section{Conclusion}

The results of the current investigation indicated that plum fruits c.v. Pioneer coated with jojoba oil, paraffin oil, glycerol and arabic gum showed a significant delay in the change of weight loss, firmness, soluble solids content and decay percentage during shelf life periods compared to uncoated ones. Also, the results of sensory evaluation suggest that jojoba oil, glycerol and Arabic gum can be successfully used as edible coatings instead of paraffin oil. So that this investigation should that using several edible coating lead to preservation of quality of plum fruits c.v. Pioneer and extend their shelf life period.

\section{References}

A.O.A.C. (1990) "Official Methods of Analysis", The Association of Official Analytical, $15^{\text {th }}$ ed. Cemist Arlington, West Virginia, USA, Washington D.C.

Abdi, N., Holford, P., McGlasson, W.B. and Mizrahi, Y. (1997) Ripening behavior and responses to .Propy lene in four cultivars of Japanese type plums. Postharvest Biology and Technology, 12, 21-34

Abdi, N., McGlasson, W.B., Holford, P., Williams, M. and Mizrahi, Y. (1998) Responses of climacteric and sup pressed-climacteric plums to treatment with propylene and 1-methy lcy clopropene. Postharvest Biology and Technology, 14, 29-39. 
Bai, J., Alleyne, V., Hagenmaier, R.D., Mattheis, J.P. and Baldwin, E.A. (2003) Formulation of zein coatings for apples (Malusdomestica borkh). Postharvest Biol. Technol., 28, 259-268.

Baldwin, E.A., Burns, J.K., Kazokas, W., Brecht, J.K., Hagenmaier, R.D., Bender, R.J. and Pesis, E. (1999) Effect of 2 edible coatings with different permeability characteristics on mango (Mangifera indica L.) ripening during storage. Postharvest Biol. Technol., 17, 215-226.

Baldwin, E.A., Niesperos, M.O. Shaw, P.E. and Burns, J.K. (1995) Effect of coatings and prolonged storage conditions on fresh orange flavour volatiles, degrees brix and ascorbic acid levels. J. Agric. Food Chem., 43, 1321-1331.

El-Anany, A.M, Hassan, G.F.A. and Rehab Ali, F.M. (2009) Effects of Edible Coatings on the Shelf - life and Quality of Anna Apple (Malus domestica Borkh) During Cold Storage. Journal of Food Technology, 7(1), 5-11, 2009.

Heimbach, J.T., Bodor, A.R., Douglass, J.S., Barraj, L.M., Cohen, S.C., Biles, R.W. and Faust, H.R. (2002) Dietary exposures to mineral hydrocarbons from food-use applications in the United States. Food Chem. Toxicol., 40, 555-571

Kader, A.A. (2000) Postharvest Technology of Horticultural Crops, Davis: University of California, pp. 15-20.

Kittur, F.S., Saroja, N. Habibunnisa and Tharanathan, R.N. (2001) Poly saccharidebased composite coating formulations for shelf-life extension of fresh banana and mango. Eur. Food Res. Technol., 213, 306-311.

Labuza, T.P. (1984) Moisture Sorption: Practical Aspects of Isotherm Measurement and Use. Association of Cereal Chemists, Minneapolis, MN.

Mancini, F. and McHugh, T.H. (2000) Fruit-alginate interactions in novelrestructured products. Nahrung, 44, 152-157.

Nasr, Samah, Hassan, I., Karkar, M. and Abd-El Hamid, A. (2013) Evaluation of Silicon Concentrations and Modified Atmosphere Packing (MAP) on Behavior of Pioneer Plums under Two Different Storage Temperatures. World Journal of Agriculture Sciences, 9 (6), 454-465, 2013

Nisperos-Carriedo, M.O. (1994) Edible Coatings and Films Based on Poly saccharides. In: Edible Coatings and Films to Improve Food Quality, Krochta, J.M., E.A. Baldwin and M.O. Nisperos-Carriedo (Ed.). Technomic Publishing Co., Switzerland, pp: 305-335.

Nussinovitch, A. (1997) "Agricultural Uses of Hydrocolloids", Blackie Academic and Professional, London, pp: 169-189.

Nussinovitch, A. (2000) Gums for Coatings and Adhesives. In: Handbook of hydrocolloids, Phillips, G. and P. Williams (Ed.). CRC Woodhead Publishing Ltd., Cambridge, England.

Park, H.J., (1999) Development of advanced edible coatings for fruits. Trends Food Sci. Technol., 10, 254-260. 
Patrícia S., Tanada-Palmu and Carlos R.F. Grosso (2005) Effect of edible wheat gluten-based films and coatings on refrigerated strawberry (Fragaria ananassa) quality. Postharvest Biology and Technology, 36, 199-208.

Rhim, J.W. (2004) Physical and mechanical properties of water resistant sodium alginate films. Lebensmittel Wiss. Und. Technol., 37, 323-330.

Rojas-Grau, M.A., Tapia, M.S. Rodriguezb, F.J., Carmonac, A.J. and Martin-Belloso, O. (2007) Alginate and gellan-based edible coatings as carriers of antibrowning agents applied on fresh-cut Fuji apples. Food Hydrocolloids, 21, 118-127.

Snedecor, G.W. and Cochran, W.G. (1982) "Statistical Methods", $7^{\text {th }}$ ed. Iowa state Univ. Press, lowa, U.S.A.

Yaman, O. and Bayoindirli, L. (2002) Effects of an edible coating and cold storage on shelf-life and quality of cherries. Lebensm. Wiss Und. Technol., 35, 146-150.

Yang, L. and Paulson, A.T. (2000) Effects of lipids on mechanical and moisture barrier properties of edible gellan film. Food Res. Int., 33, 571-578.

Zuzunaga, M., Serrano, M., Martinez-Romero, D., Valero, D. and Riquelme, F. (2001) Comparative study of two plum (Prunus salicina Lindl.) cultivars during، growth and ripening. Food Science and Technology International, 7, 123-30.

(Received 2/10/2014; accepted 4/2/2015)

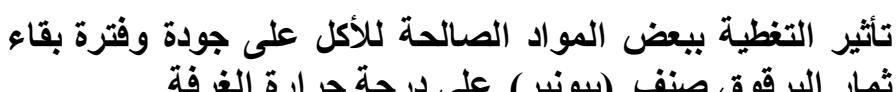

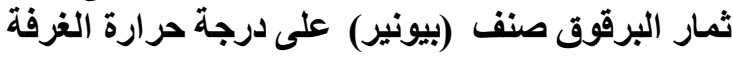

$$
\text { قحم البساتين ـ كلية الزر اعة ـ جامعة عين شمس - القاهرة - مصر. }
$$

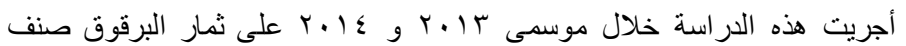

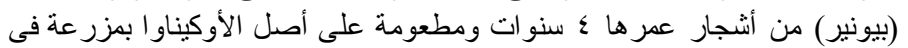

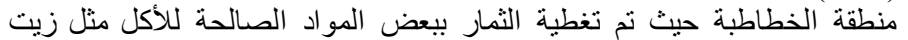

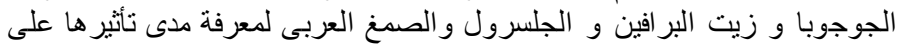

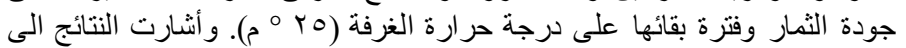

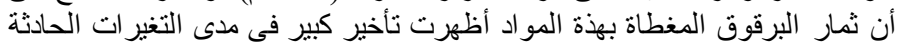

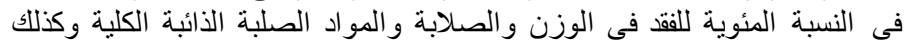
نسبة التالف من الثمار مقارنة بالثمار غير المغطاة.

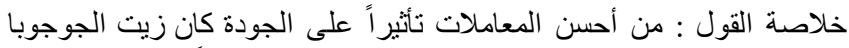

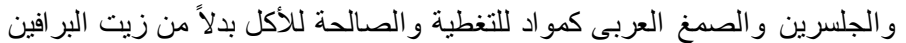
و الثمار غير المغطاه الكنترول. ت ولين.

Egypt. J. Hort. Vol. 42, No. 1 (2015) 